\title{
The Impact of Short-Term Interest Rates on Bank Funding Costs
}

\author{
Azasakhe Nkcubeko Nomsobo ${ }^{1}$, Roscoe Bertrum van Wyk ${ }^{2}$ \\ ${ }^{1}$ University of Fort Hare, East London, South Africa \\ 2University of Stellenbosch Business School, Stellenbosch University, Cape Town, South Africa \\ anomsobo@gmail.com,roscoevanwyk@gmail.com
}

\begin{abstract}
This study examines the impact of short-term interest rates on bank funding costs in South Africa. Literature suggests that rising short-term interest rates may cause similar financial crises experienced in 2007/08 (Bonner \& Eijffinger, 2013; Turner, 2013; Saraç \& Karagoz, 2016). It is vital to study short-term interest rates and bank funding costs in order to achieve financial stability. The study uses quarterly time series data for the period 2000 to 2014. To estimate the regression, the study uses the Vector Autoregressive model (VAR) and the data is found stationary at first difference. The 3 months Johannesburg Interbank Agreed Rate (JIBAR) is used as a proxy for bank funding costs whilst the prime overdraft rate, 10-year government bonds and capital ratio are used as proxies for short-term, long-term interest rates and bank capital, respectively. The results show a positive and significant long-term relationship between the variables. The results for prime overdraft rate, 10-year government bonds and capital ratio conform to the apriori expectations. For GDP growth the results show a positive relationship which does not conform to apriori expectations. Using the variance decomposition, the study illustrates fluctuations in JIBAR was due to changes in its value and fluctuations in the prime rate are also due to JIBAR. The study presents policy options whereby regulatory efforts need to strengthen the capital buffers of banks to reduce bank funding costs and therefore reduce short-term interest rates imposed on borrowers.
\end{abstract}

Keywords: Bank funding costs, short-term interest rates, long-term interest rates

\section{Introduction}

Banks are required to fund their business activities. Funding is done by lending at interest rates that are higher than the cost of the money they lend. Banks have a wide variety of funding such as deposits, capital (equity) and debt issuance (short term and long term debts) (Wong, 2012). The costs of funding have a significant impact on the economy because these costs are necessary to the transmission mechanism of monetary policy and growth (Beau et al., 2014). Bank funding costs is important for monetary policy stability as it affects the outlook for growth and inflation. This was not noticed during the recent financial crisis as the bank's funding costs increased relative to risk-free interest rates and implied an upward pressure on lending rates. Bank funding costs are also important for financial stability. When funding costs increase, the bank's profitability will decrease. This occurs when the bank chooses to absorb higher costs and leaving its loans unchanged. When funding costs increase, banks may pass increasing costs to borrowers by increasing rates charged on new loans. When the cost of credit is high, the overall economic activity will be negatively affected, this causes higher costs of servicing debt and increases the number of default payments. This will weigh down the bank's profitability because the credit loses faced by the banks.

When the bank's profitability decreases, its capital may be eroded and create risks to the financial stability and solvency. The bank funding costs are derived from money market yield curves; and via these yield curves the repo rate has an indirect effect on lending rates of banks. Alternatively lending rates are determined by the cost of funding, creditworthiness or credit risk profile of the client (du Plooy et al., 2009). The key drivers of bank funding costs are deposit rates and wholesale funding rates and deposits being the largest source. Before the 2007/08 global financial crisis, wholesale funding was the largest source of bank funding, contributing approximately half of the total funding in the five years leading up to the financial crisis (Wong, 2012). Wholesale funding may be short term or long term. Short-term funding costs include one month or three months Treasury bill rates and interbank rates. Interbank lending is markets where banks make loans to each other. Most of these loans have maturities of one week or less and most of them being overnight. The 2007/08 global financial crisis was caused by low transaction volumes in the interbank markets (Temizsoy et al., 2014). 
In order for a bank to manage panics by its clients, it must liquid assets in hand such as cash, and in a case where the bank does not have or does not hold these liquid assets it will have to borrow from the interbank markets (Bonner \& Eijffinger, 2013). The bank borrowing a short term loan or asset from another bank will be charged the interbank rate. These rates may depend on the money available in the market, existing rates or on the agreement between the institutions. A rise in these rates may cause financial crisis similar to that experienced in 2007 (Bonner \& Eijffinger, 2013; Turner, 2013; Saraç \& Karagöz, 2016, Makatjane et al., 2018). The short term interest rates are very important for financial stability. It is important to study how they affect the cost of funding for banks so that we can avoid financial instabilities. The principal objective of this study is to assess the impact of short term interest rates on bank funding costs. The specific objectives include (1) Examining trends in short term interest rates and bank funding costs, (2) econometrically examine the impact of short term interest rates on bank funding costs; and (3) based on the empirical results, articulate policy implications of studies related to this one.

\section{Literature Review}

Interest Rate Theory: Post Keynesian's believed that the neo classical economists misinterpreted Keynes' views. Although they have maintained the ideologies of Keynes (1936), they differed in the sense that money supply is an exogenous variable. Rogers (1986) believed that Post Keynesians view could be closely related to the present central banking system. The neo classical economists viewed money as an exogenous variable. They believed that interest rates are determined by market demand and supply in the general equilibrium neo classical system. According to Calitz et al. (1999), post Keynesians opposed the view of neo classical economists as they maintained that money supply is endogenous and interest rates are exogenous variables. They argue that interest rates are exogenous variables because the neo classical general equilibrium does not explain interest rates. Moore (1988) maintains that short term interest rates are exogenously determined by the central bank to achieve its policy goals. Central banks can thus establish interest rates on all bank wholesale short term securities, which affect the general market short term interest rates.

The Loanable Funds Theory: Robertson and Ohlin (1930) developed the loanable funds theory, which is an extension of the classical theory, which maintains that savings and investments are the determinants of bank credit. The loanable funds theory is used in determining long term interest rates and is also used to check the causes of interest rates volatility by looking at the demand for and supply of credit. The neoclassical theory maintains that households use their income for either consumption or savings. Savings mean that an individual will defer his/her consumption and this for either option the individual choose there will be an opportunity cost. The interest rate then will be the opportunity cost for consuming. When interest rates are high then individuals will be willing to save because they will be getting high return. This means that supply of credit will increase when interest rates increase. According to this theory the savings function is as follows: $\mathrm{S}=\mathrm{S}(i)$; where $\mathrm{S}$ represent savings and $i$ shows the interest rates. In this theory the demand for loanable funds is represented by investments, thus the investment is a negative function of interest rates. This is because the interest rate in this case will be representing the cost of funding. When interest rates are low then it will be more profitable to invest, so investors will be willing to borrow and invest these borrowed funds in a more profitable project. The investment function is written as: I = I (i); where I show the investments and $i$ show the interest rates. This theory can be used to explain the impact of interest rates of the bank funding costs. When interest rates increase then depositors will receive high returns meaning that the bank is incurring more cost. This shows a positive relationship between bank funding and the cost of funding for banks. So when the monetary authorities increase interest rates the bank funding cost will increase.

Bank Funding Costs, Monetary Stability and Financial Stability: The price that banks pay as a way to replace their liabilities is bank funding costs. To set the interest rate offered to its clients, the bank will need to add its cost of funding and compensation for risk associated with default payment from households or firms, add any operating cost experienced by the bank and add any mark-up over costs (Button et al., 2010). This is an indication that banks manage their balance sheet like any other business to maintain its profits and that will help them to determine their costs of funding which enables them to set interest rate to charge for loans. A bank's profitability is the difference between interest rates and cost of funding. The notion of Net Interest Margin refers to the bank's profitability. According to Beau et al. (2014) the net interest margin 
(bank's profitability) declines when cost of funding increase holding interest rates constant. Rising funding costs in relation to cash rates is a reflection of increased competition for term deposits and a high spread of wholesale debt which indicates a rising concern by investors about the banking industry (Deans \& Stewart, 2012).

To view the relationship between bank funding costs, profitability and interest rates, let's consider a situation where the bank has experienced a spike in bank funding costs by making a simple example. Let's assume before the shock the cost of funding paid was $4 \%$ annually and that this interest rate represents the cost of funding i.e. marginal and average cost of funding. The bank also charges a $6 \%$ interest rate to its clients for loans. The shock in funding costs results in the bank increasing interest rates sharply from $4 \%$ to $9 \%$. The bank will respond by either absorbing the costs therefore reduce their profits or they might maintain their profits and pass the costs to their clients by increasing the prime interest rates. When the bank absorbs the costs it means that it will continue to charge $6 \%$ to its clients and that will result in marginal funding to decrease profitability and thus create financial instability due to the bank's solvency declining. When the banks transfer these costs to its clients and maintain its profits say to $12 \%$ for new loans, the monetary instability will be affected as the increase in price of credit reduces aggregate output, household income and investment (Terblanche \& De La Rey, 2013).

When economic activities decrease then that will mean that borrower will be unable to repay their loans and lead lower profits for banks and result in financial instability. This is what caused the recent global financial crisis. Many central banks using the inflation targeting framework have the main objective to achieve monetary stability ( $O^{\prime}$ Connell, 2008). The monetary authority sets its inflation target by adjusting the repo rate. The repo rate affects short term market interest rates which also affect prime interest rate set by banks and other financial institutions and thus affects price of financial instruments. This movement in interest rates affects aggregate spending and general prices (Nyawo \& van Wyk, 2018). The South African Reserve Bank 's (SARB) major objective is to maintain monetary stability and this is done by targeting inflation and the monetary policy committee is responsible for setting repo rate and other interest rates. SARB has a role to improve stability in the financial system. SARB uses micro prudential supervision which monitors the health and soundness of the financial system (Muneer et al., 2011).

Empirical Studies: A study by Raknerud and Vatne (2012) used quarterly panel set for all Norwegian banks to study the relationship between bank funding cost and interest rates. The cost of funding was estimated using 91 days Norwegian Interbank Offer Rate (NIBOR). The results showed that an increase in NIBOR led to an approximately 0.8 increase in bank's loan rate in the long run. The study found clear evidence showing pass through from the NIBOR to the loan rates. Similarly, Raknerud et al. (2011) examined the impact of bank funding costs on interest margin on Norwegian banks. The study used dynamic factor model and panel data set with quarterly accounts data. Sources of bank funding was categorized into deposit and long term wholesale funding where the cost of funding was represented by the spread of unsecured bonds issued by commercial banks and 3 months NIBOR. The findings were consistent with the view that bank's loans had a downward sloping demand curve and consumer deposit have an upward sloping supply curve. Derviz et al. (2009) examined the relationship between funding costs and lending rates. In their investigation they used the model of loan pricing by banks where they (banks) lent to risky creditors. They investigated the comparative statistic of the lending rate changes to bank funding costs, this depended on imperfect information. The results showed that bank's influence was pronounced in interest rates on loans to small and local clients that had small information. Cube et al. (2012) examined the long term relationship between lending rates and funding rates. The study used monthly data from the South African Reserve Bank for the period of 1992 to 2011. The study used the Engle-Granger two step model and error correction equation to estimate the long-term relationship between lending rates and funding rates. The results of the study showed evidence of a pass-through from lending rates to funding rate changes and it was greater when funding rates increased than when they decreased. The study concluded that longer term maturity funding costs were more volatile than short term funding costs because the premium of a term depended on expectations and economic conditions. The empirical studies show that there is a pass-through from interest rates to bank funding costs. This means that interest rates increase offsets the bank funding costs. The studies also showed that there is a positive relationship between these variables. When interest rates increase the bank funding costs also increase. 


\section{Methodology}

Study Design: A quantitative/econometric approach is used in this study to analyse the impact of short term interest rates on bank funding costs in the case of South Africa. The study will employ the Vector AutoRegressive (VAR) modelling technique. Empirical evidence has revealed that most studies suggest that interest rates have a positive relationship with bank funding costs.

Data collection: The study utilises annual data for the period 2000 to 2014 to analyse trends in the variables 7 years prior and after the 2007/08 recessions as well as trends after recession. This also allows for the credibility and frequency of the observations. The data used in this study was accessed from the online statistical query of the various websites. The data for the 3 months Johannesburg Interbank Agreed Rate (JIBA) rate, prime interest rates (short term interest rates) and 10-year government bonds (long term interest rates) were sourced from the South African Reserve Bank website. The data for bank capital to asset ratio and GDP growth was obtained from the World Bank website.

Model Specification: The study developed the regression model as follows:

$\mathrm{FC}=\mathrm{f}$ (intS, intL, cap, gdp)

Where FC = bank funding costs (3 months JIBAR);

int $=$ short term interest rates;

intL = long term interest rates;

cap = capital to asset ratio; and gdp = GDP growth

The empirical model to be used in the study is estimated below:

$\mathrm{FC}_{\mathrm{t}}=\alpha_{\mathrm{t}}+\beta_{1}$ int $S_{\mathrm{t}}+\beta_{2}$ int $\mathrm{L}_{\mathrm{t}}+\beta_{3}$ cap $-\beta_{4} \mathrm{gdp}_{\mathrm{t}}+\mu_{\mathrm{t}}$

Estimation Techniques: The model above utilises the 3 month JIBAR as the proxy of bank funding cost. JIBAR is the rate that is published by the JSE that used as a reference floating interest rate for transactions denominated in Rand (Botha, 2002). The 3 months JIBAR is for instruments that have a maturity of 3 months. The prime overdraft rate is a proxy for short term interest rates. The prime overdraft rate is the lowest rate at which a commercial bank will lend money to its clients on overdraft (Eatwell et al., 1987). According to the trend analysis and theoretical literature it is expected that the prime overdraft interest rates will have a positive relationship with bank funding costs. Long term interest rates will be represented by 10 -year government bonds. 10-year Government bonds are long term securities issued in the capital market or bond market by the central government that have a maturity of 10 years.

Unit Root Testing: It is then important that the data should be tested for stationarity before running regression. The study will commence with unit root analysis. It is important to first test for stationarity to avoid results and regressions that are spurious. The unit root testing uses the Augmented Dickey-Fuller test and Phillips-Peron test. The results of the unit tests, Augmented Dickey Fuller and Phillips Peron tests and are shown in table 1 and 2 below. Table 1 shows the unit root test at level series results. The unit root test results at this point show that JIBAR and Prime rate are not stationary at level series for both ADF and PP tests whilst government bonds and GDP growth are stationary. This means that variables need to be tested at first difference until some stationarity is detected.

Vector Autocorrelation Model (VAR): The study will use the VAR model to analyse the dynamic interaction among the variables. It should be considered that some explanatory variables, bearing the fact that bank funding costs also affects other variables either directly or indirectly so that the VAR model is stable and under specification of the model is avoided. When analysing the results of the vector autoregressive model, the first step is to select the appropriate lag length for the variables. When picking the appropriate lag length, the study makes use of the Akaike Information Criteria and Schwarz Bayesian Criteria. Table 3 represent the two selection criteria. The lag length of both the Akaike Information Criteria and Schwarz Bayesian Criteria is selected at lag 1. The study will select both Akaike Information Criteria and Schwarz Bayesian Criteria and use 1 lag. 
Table 1: Unit root Tests-Level series

\begin{tabular}{lllllll}
\hline Variable & ADF & & PP & \\
& Intercept & $\begin{array}{l}\text { Intercept and } \\
\text { trend }\end{array}$ & None & Intercept & $\begin{array}{l}\text { Intercept and } \\
\text { trend }\end{array}$ & None \\
JIBAR & -1.547749 & -2.574612 & -0.824225 & -1.644554 & -2.793830 & -0.824576 \\
Prime & -2.328926 & $-3.642622^{* *}$ & -0.919380 & -1.562619 & -2.336449 & -0.969375 \\
rate & & & & & \\
Bonds & $-3.892491^{* * *}$ & $-4.738077^{* * *}$ & -1.197272 & $-3.656661^{* * *}$ & $-4.738077^{* * *}$ & -1.373727 \\
Cap & -2.332969 & -2.420765 & -0.566231 & -2.427609 & -2.576793 & -0.566231 \\
Gdp & $-4.153577^{* * *}$ & $-4.297686^{* * *}$ & $-1.686032^{*}$ & $-4.070625^{* * *}$ & $-4.297686^{* * *}$ & $-2.087009^{* *}$
\end{tabular}

Notes: * significant at $10 \%$; ${ }^{* *}$ significant at $5 \%$; ${ }^{* * *}$ significant at $1 \%$

Table 2 shows the unit root test results at first difference. Different from the results of unit root tests at level series, the variables show stationarity at first difference. Both tests reveal that the variables are stationary and though Philips-Perron tests are more consistent from a robustness perspective, the results reveal some similarity in the sense that almost all the variables have some significance at the $1 \%$ level. The results are mixed but in the data are stationary at first difference.

Table 2: Unit root tests-1st difference level

\begin{tabular}{lllllll}
\hline Variable & ADF & \multicolumn{5}{l}{ PP } \\
\hline & Intercept & $\begin{array}{l}\text { Intercept and } \\
\text { trend }\end{array}$ & None & Intercept & $\begin{array}{l}\text { Intercept and } \\
\text { trend }\end{array}$ & None \\
JIBAR & $-8.269744^{* * *}$ & $-8.193927^{* * *}$ & $-8.303111^{* * *}$ & $-8.239164^{* * *}$ & $-8.168465^{* * *}$ & $-8.270040^{* * *}$ \\
Prime rate & $-3.555856^{* * *}$ & $-3.524298^{* *}$ & $-3.552573^{* * *}$ & $-3.683490^{* * *}$ & $-3.652962^{* *}$ & $-3.678702^{* * *}$ \\
Bonds & $-12.46279^{* * *}$ & $-7.784929^{* * *}$ & $-12.44367^{* * *}$ & $-15.90518^{* * *}$ & $-20.86753^{* * *}$ & $-14.41021^{* * *}$ \\
Cap & $-7.497693^{* * *}$ & $-7.457418^{* * *}$ & $-7.549834^{* * *}$ & $-7.497693^{* * *}$ & $-7.457418^{* * *}$ & $-7.549834^{* * *}$ \\
Gdp & $-10.54532^{* * *}$ & $-10.45387^{* * *}$ & $-10.64034^{* * *}$ & $-13.61298^{* * *}$ & $-13.39422^{* * *}$ & $-5.722492^{* * *}$ \\
\hline
\end{tabular}

Notes: ${ }^{*}$ significant at $10 \% ;{ }^{* *}$ significant at $5 \% ;{ }^{* * *}$ significant at $1 \%$

\section{Findings}

Johansen Cointegration Test: Cointegration occurs in time series variables when there is stationarity in the error term in a regression model. Cointegration has been seen as one of the important properties in time series. The test involves finding the number of cointegrated vectors. In this step the Trace and Maximum eigenvalue test are used in table 4 and 5 . The trace tests reject the hypothesis at $5 \%$ level. As per the cointegration test tables below, there are four cointegration relationships between the time series. Table 6 show the normalised cointegration vector on JIBAR.

Table 3: Selection of the Lag Length

\begin{tabular}{lll}
\hline Leg Length & Akaike Information Criteria & Schwarz Bayesian Criteria \\
\hline 0 & 13.30943 & 13.49192 \\
$1^{*}$ & $9.263649^{*}$ & $10.35856^{*}$ \\
2 & 9.191310 & 11.19864 \\
3 & 9.553320 & 12.47308 \\
4 & 9.410061 & 13.24224 \\
5 & 9.584419 & 14.32902 \\
\hline
\end{tabular}


Table 4: Unrestricted Cointegration Rank Test (Trace)

\begin{tabular}{lclll}
\hline $\begin{array}{l}\text { Hypothesized } \\
\text { No. of CE(s) }\end{array}$ & Eigenvalue & Max-Eigen Statistic & 0.05 Critical Value & Prob.** \\
\hline None & 0.382015 & 65.38203 & 69.81889 & 0.0003 \\
At most 1 & 0.258548 & 37.94846 & 47.85613 & 0.0002 \\
At most 2 & 0.201839 & 20.89720 & 29.79707 & 0.0024 \\
At most 3 & 0.098708 & 8.046839 & 15.49471 & 0.0005 \\
At most 4 & 0.036562 & 2.123066 & 3.841466 & 0.0051 \\
\hline
\end{tabular}

Table 5: Unrestricted Cointegration Rank Test (Maximum Eigenvalue)

\begin{tabular}{lclll}
\hline $\begin{array}{l}\text { Hypothesized } \\
\text { No. of CE(s) }\end{array}$ & Eigenvalue & Trace Statistic & $\mathbf{0 . 0 5}$ Critical Value & Prob.** \\
\hline None & 0.382015 & 27.43357 & 33.87687 & 0.0000 \\
At most 1 & 0.258548 & 17.05126 & 27.58434 & 0.0000 \\
At most 2 & 0.201839 & 12.85036 & 21.13162 & 0.0000 \\
At most 3 & 0.098708 & 5.923773 & 14.26460 & 0.0005 \\
At most 4 & 0.036562 & 2.123066 & 3.841466 & 0.0051 \\
\hline
\end{tabular}

Table 6: The Cointegration Vector of Variables

\begin{tabular}{llllll}
\hline Variable & JIBAR & Prime Rate & Government Bonds & $\begin{array}{l}\text { Capital to } \\
\text { Asset Ratio }\end{array}$ & GDP growth \\
\hline Coefficient & 1.000000 & -0.943629 & -0.596631 & -4.019290 & -0.392559 \\
Standard Error & & $(0.09292)$ & $(0.16964)$ & $(1.25502)$ & $(0.11918)$ \\
t-stat & & -10.15528 & -3.51704 & -3.202571 & -3.29383 \\
\hline
\end{tabular}

The long run equilibrium equation showing the cointegration relationship between the variables is shown below FC $=0.943620 \mathrm{i}_{\mathrm{s}}+0.596631 \mathrm{i}_{\mathrm{L}}+4.019290 \mathrm{cap}+0.392559 \mathrm{gdp}$. The normalised equation indicates that there is a positive long term relationship between short term interest rates (prime rate), long term interest rates (government bonds) and GDP growth with bank funding costs (JIBAR) at 95\% level of confidence. There is a positive relationship between all the independent variables and the dependant variable.

Variance Decomposition: Variance decomposition studies the usefulness of each variable in the volatility of other variables. It can also be said that it studies how much information each variable contributes to the other variables in the autoregression. Table 7 illustrates the results of the variance decomposition. The shocks of each variable on other variables is shown for first, fifth and tenth years. On the table the first column shows the variables, the second column shows the years and the third is the standard error. At first, on 1 year the study shows that $100 \%$ of the fluctuations on the JIBAR are due to shocks the variable itself. Fluctuations in prime rate, government bonds and GDP growth do not have an influence in the JIBAR after 1 year. After 5 years the study shows that $80 \%$ of the fluctuations in the JIBAR are due to shocks in the variable itself whilst $12 \%, 1 \%, 1 \%$ and $6 \%$ of fluctuations are due to shocks from prime rate, government bonds, capital and GDP growth. After 10 years the results show that $73 \%$ of the volatility in JIBAR was due to shocks resulting from the variable itself. After 1 year, $37 \%$ of changes in the prime rate on are due to shocks on the variable itself, whilst $63 \%$ of the fluctuations in the JIBAR. After 5 years, $18 \%$ of the volatility in prime rate was due to shocks resulting from the variable itself whilst $75 \%, 1 \%, 1 \%$ and $5 \%$ of fluctuations in the prime rate are due to shocks in JIBAR, government bonds, capital and GDP growth. $11 \%$ of volatility in prime rate after 10 years has resulted from the variable itself. $70 \%, 1 \%, 13 \%$ and $5 \%$ of volatility in prime rate is due to JIBAR, government bonds, capital and GDP growth. Finally, after 1 year, $91 \%$ of changes in the GDP growth are due to shocks on the variable itself, whilst 7\%, $0 \%, 0 \%$ and $1 \%$ of the fluctuations in GDP growth are due to JIBAR, prime, government bonds and capital. After 5 years, $60 \%$ of the volatility in GDP growth was due to shocks resulting from the variable itself whilst $6 \%, 17 \%, 2 \%$ and $13 \%$ of fluctuations in the GDP growth are due to shocks in JIBAR, prime rate, government bonds and capital. After 10 years $9 \%, 17 \%, 2 \%$ and $16 \%$ of volatility in GDP growth is due to JIBAR, prime rate, government bonds and capital respectively, whilst $56 \%$ is due to the variable itself. 
Table 7: Variance Decomposition

\begin{tabular}{llllllll}
\hline $\begin{array}{l}\text { Variance } \\
\text { Decomposition }\end{array}$ & Year & S.E & JIBAR & $\begin{array}{l}\text { Prime } \\
\text { Rate }\end{array}$ & Gvt Bonds & $\begin{array}{l}\text { Capital to } \\
\text { Asset Ratio }\end{array}$ & $\begin{array}{l}\text { GDP } \\
\text { Growth }\end{array}$ \\
\hline JIBAR & 1 & 0.990785 & 100.0000 & 0.000000 & 0.000000 & 0.000000 & 0.000000 \\
& 5 & 2.189864 & 79.62399 & 12.31360 & 1.145748 & 1.185633 & 5.731029 \\
& 10 & 2.710134 & 72.99257 & 8.507584 & 0.960018 & 11.92370 & 5.616132 \\
Prime Rate & 1 & 0.520299 & 63.04647 & 36.95353 & 0.000000 & 0.000000 & 0.000000 \\
& 5 & 1.955464 & 75.06336 & 18.00400 & 1.260677 & 1.057011 & 4.614957 \\
& 10 & 2.523397 & 69.57650 & 11.40348 & 1.083217 & 13.19951 & 4.737291 \\
$\begin{array}{l}\text { Government } \\
\text { Bonds }\end{array}$ & 1 & 1.134054 & 25.97897 & 21.50202 & 52.51902 & 0.000000 & 0.000000 \\
& 5 & 1.344308 & 23.55547 & 17.66883 & 54.84856 & 3.900795 & 0.026339 \\
& 10 & 1.443353 & 25.92807 & 15.64090 & 50.07597 & 8.233261 & 0.121805 \\
$\begin{array}{l}\text { Capital to Asset } \\
\text { Ratio }\end{array}$ & 1 & 0.114884 & 10.40858 & 2.115610 & 0.899485 & 86.57633 & 0.000000 \\
& 5 & 0.198727 & 6.061930 & 6.149181 & 0.943266 & 85.72004 & 1.125588 \\
& 10 & 0.210976 & 6.552923 & 6.501019 & 2.509902 & 82.36197 & 2.074183 \\
& 1 & 1.917946 & 8.623439 & 0.038489 & 0.031891 & 0.733274 & 90.57291 \\
& 5 & 2.581654 & 7.538128 & 16.96674 & 2.328457 & 12.96707 & 60.19961 \\
& 10 & 2.696260 & 8.547676 & 17.43769 & 2.265020 & 16.16790 & 55.58171 \\
\hline GDP growth & & & & & & &
\end{tabular}

\section{Conclusion and Policy Recommendations}

The purpose of this study was to examine the impact of short term interest rates on bank funding costs in the context of South Africa. The results showed that there is a significant positive long term relationship between all the independent variables (short term interest rates, long term interest rates, capital to asset ratio and GDP growth) with the dependent variable (JIBAR). The results conform to the apriori expectations but this was not the case with the GDP growth as it was expected to have a negative relationship with the dependent variable (JIBAR). The variance decomposition test showed that after first, fifth and tenth years, most shocks to the bank funding costs were due to fluctuations from short term interest rates. The study by Raknerud and Vatne (2012), which was studying the relationship between bank funding costs and interest rates also showed a positive relationship between bank funding costs ( 91 days NIBOR) and interest rates. A study by Ncube et al. (2012) also examined the long-term relationship between lending rate and funding rates. The results of the study showed evidence of a pass-through from lending rated to funding rate changes and it was greater when funding rates increased than they decreased. Both these studies i.e. Raknerud and Vatne (2012) and Ncube et al. (2012) show the same results as this study.

Vector Autoregressive Model Results: From the results obtained from this study, the following policy options can be recommended. Firstly, authorities and regulators should notice that short term interest rates are important in the determination of bank funding cost, as short term interest rates have a significant impact on financing by banks. Regulatory efforts from monetary authorities need to strengthen the capital buffers of banks to reduce bank funding costs and therefore reduce short term interest rates imposed on borrowers. As 
countries are normalizing their monetary policies and the implementation of Basel III capital frame works in 2019, these policies will of cause have an effect on the cost of bank funding. This means that monetary authorities and commercial banks should make it important to observe measures of bank funding costs especially the measure which is the short term interest rates.

\section{References}

Beau, E., Hill, J., Hussain, T. \& Nixon, D. (2014).Bank funding costs: what are they, what determines them and why do they matter? London: Bank of England.

Bonner, C. \& Eijffinger, S. (2013). The Impact of the Liquidity Coverage Ratio on the Interbank Money Market. Amsterdam.

Botha, Z. (2002). The money market, in Understanding South African financial markets. Pretoria: Van Schaik Publishers.

Button, R., Pezzini, S. \& Rossiter, N. (2010). Understanding the price of new lending to households. Bank of England Quarterly Bulletin, 50(3), 172-182.

Calitz, E., Siebritz, F. K. \& Mohr, P. J. (1999). Economic Policy in South Africa. University of South Africa.

Derviz, A., de Haas, R. \& van Lelyveld, I. (2009). Funding Costs And Lending Rates: Theory and Application to Loan Pricing by Multinational Bank Affiliates.Czech National Bank, Monetary and Statistics Department, 1-28.

du Plooy, R. M., Coovadia, C., Brink, N., Kock, M., Khosa, T. \& Brits, M. (2009). The Role of the Prime Rate and the Prime-Repurchase Ratespread in the South African Banking System. Pretoria: South African Reserve Bank and Bank Assosiation South Africa.

Eatwell, J., Milgate, M. \& Newman, P. (1987). The New Palgrave: A Dictionary of Economics.London: The Macmillan Press Limited.

Makatjane, K. D., Molefe, E. K. \& van Wyk, R. B. (2018). The Analysis of the 2008 US Financial Crisis: An Intervention Approach. Journal of Economics and Behavioral Sciences, 10(1), 59-68.

Moore, B. J. (1988). Horizontalists and Verticalists: The Macroeconomics of Credit Money. Cambridge: Cambridge University Press.

Muneer, S., Butt, B. Z. \& Rehman, K. U. (2011). A Multifactor Model of Banking Industry Stock Returns: An Emerging Market Perspective. Information Management and Business Review, 2(6), 267-275

Ncube, M., Ndou, E., Ndlovu, M. \&Gumata, N. (2012). Lending Rate Stickiness, Asymmetry Between Lending Rates and Funding Costs in South Africa. 1-25.

Nyawo, S. T. \& van Wyk, R. B. (2018). The Impact of Policy Uncertainty on Macro-Economy of Developed and Developing Countries. Journal of Economics and Behavioral Sciences, 10(1), 33-41.

0' Connell, S. A. (2008). Inflation Targeting as a Monetary Policy Framework: Issues and Concerns. Swarthmore College. Pennsylvania.

Raknerud, A. \& Vetne, B. H. (2012). The Relation Between Banks' Funding Costs, Retail Rates and Loan Volumes: An Analysis of Norwegian Bank Micro Data. Norges Bank, 1-36.

Raknerud, A., Vatne, B. H. \& Rakkestad, K. (2011). How Do Banks' Funding Costs Affect Interest Margins? Working Paper:Norges Bank, 1-28.

Rogers, C. (1986(1)). The Theory of Monetary Policy Revisited. Journal for Studies in Economics and Econometrics, 3, 13-49.

Rogers , C. (1986(2)). The De Kock Report: A Critical Assessment of the Theoretical Issues. South African Journal of Economics, 3, 66-79.

Sarac, T. B. \& Karagoz, K. (2016). Impact of Short-term Interest Rate on Exchange Rate: The Case of Turkey. Procedia Economics and Finance, 38(1), 195-202.

Temizsoy, A., Iori, G. \& Montes-Rojas, G. (2014). The Role of Bank Relationships in the Interbank Market. London: City University London.

Terblanche, S. E. \& De La Rey, T. (2013). Credit Price Optimisation within Retail Banking. Center for Business Mathematics and Informatics. North-West University, Potchefstroom.

Turner, P. (2013). Why the long-term interest rate matters. Bank for International Settlements. London.

Wong, J. (2012). Bank Funding-The Change in Composition and Pricing. Wellington: Reserve Bank of New Zealand: Bulletin, Vol. 75. 